\title{
Dioxin concentrations in the blood of workers at municipal waste incinerators
}

\author{
Arnold Schecter, Olaf Päpke, Michael Ball, Anton Lis, Paul Brandt-Rauf
}

\begin{abstract}
Objectives-Increased concentrations of polychlorinated dibenzo-p-dioxins (PCDDs) and polychlorinated dibenzofurans (PCDFs) in pooled blood samples from workers at municipal waste incinerators have been reported. This study was undertaken to confirm these results in individual blood samples from potentially exposed and unexposed workers at municipal waste incinerators compared with matched unexposed controls and compared with concentrations in the slag and fly ash from the municipal waste incinerators.
\end{abstract}

Methods-Concentrations of PCDDs and PCDFs were determined in the blood of 10 workers from an old municipal waste incinerator without adequate pollution controls, 11 workers from a newer incinerator with modern pollution controls, and 25 controls from the general population group matched for age ( \pm 10 years), sex, and race, and in the slag and fly ash from the older incinerator.

Results-Significant increases of certain PCDDs and PCDFs were found in the blood of the workers from the older incinerator compared with the controls as follows: octaCDD (1051 (438) $v 637$ (344), $\mathbf{P}<0.001)$, hexaCDF (52.3 (28.7) $v$ $30.2(18.2), P<0.01)$, heptaCDF (43.9 $(30.4)$ v $22.7(12.4), \quad P<0.001)$, total PCDDs (1262 (484) v 825 (454), $P<$ 0.001), total PCDFs $(133.0(68 \cdot 1) v 93.7$ (36.7), $P<0.05)$, and total PCDD/Fs (1395 (537) $v 918$ (437), $P<0.001$ ). The workers from the older incinerator with the greatest exposure were found to have the most significant increases of the blood PCDDs and PCDFs, and the pattern of increased PCDD and PCDF congeners in the blood corresponded to the pattern in the incinerator slag and ash. No significant differences were found between the blood concentrations of the workers at the newer incinerator and the controls.

Conclusion-Occupational exposure to slag and fly ash from municipal waste incinerators may increase the blood concentrations of PCDDs and PCDFs. Modern pollution control technology in new incinerators may be able to minimise potential exposure to slag and fly ash and thus the absorption of PCDDs and PCDFs from this source.

(Occup Environ Med 1995;52:385-387)
Keywords: municiple waste incinerators; dioxins; dibenzofurans

Polychlorinated dibenzo-p-dioxins (PCDDs) and polychlorinated dibenzofurans (PCDFs) are chemically similar tricyclic compounds that are ubiquitous environmental contaminants. These chemicals have been found in human tissue samples from locations around the world. ${ }^{1}$ As PCDDs and PCDFs have long been shown to be highly toxic to certain animal species, ${ }^{2}$ there has been concern about the extent of health effects to humans from environmental exposures. ${ }^{3}$

The incineration of municipal waste is thought to be an important potential source of these chemicals in the environment. Analyses of incinerator ash and incinerator emissions have shown the presence of PCDDs and PCDFs. ${ }^{45}$ The PCDDs and PCDFs in such incinerator wastes may be bioavailable and contribute to human body burdens of these compounds. For example, we previously reported an increase in certain PCDD and PCDF congeners in the pooled blood of 56 workers at municipal waste incinerators from the United States in comparison with pooled blood of 14 unexposed matched controls. ${ }^{6}$ To investigate this further, in the present study we analysed individual blood samples for PCDDs and PCDFs from two cohorts of German incinerator workers: one group of 10 workers from an older incinerator built before adequate pollution controls were in place, and a group of 11 workers from a newer incinerator with modern pollution controls. These results were compared with concentrations of PCDD and PCDF of individual blood samples from 25 German controls from the general population group matched for age, sex, and race. Also, concentrations of PCDD and PCDF were measured in the slag and fly ash from the older incinerator.

\section{Materials and methods}

Three cohorts were selected for this study. The first cohort was a group of 10 employees at an old municipal incinerator in southern Germany. According to information supplied by the employer from employee questionnaires, they were all white men with a mean (range) age of $43(33-52)$ years and $11 \cdot 1$ (2-14) years working in municipal waste incineration. From the job description of these workers, it was determined that the job classification of locksmith included the highest likelihood of exposure to incinerator slag and ash, as these workers were involved in 
$P C D D / P C D F$ in the blood of workers in municipal waste incinerators and controls and in slag and fly ash

\begin{tabular}{|c|c|c|c|c|c|c|}
\hline \multirow[b]{2}{*}{ Congeners } & \multirow[b]{2}{*}{$\begin{array}{l}\text { Controls }(n=25) \\
\text { mean (SD, range) } \\
\text { (ppt, lipid) }\end{array}$} & \multirow[b]{2}{*}{$\begin{array}{l}\text { Newer incinerator } \\
\text { workers }(n=11) \\
\text { mean }(S D, \text { range }) \\
\text { (ppt, lipid) }\end{array}$} & \multicolumn{2}{|l|}{ Older incinerator } & \multirow[b]{2}{*}{$\begin{array}{l}\text { Slag } \\
(p p b)\end{array}$} & \multirow[b]{2}{*}{$\begin{array}{l}\text { Ash } \\
(p p b)\end{array}$} \\
\hline & & & $\begin{array}{l}\text { Total workers }(n=10) \\
\text { mean (SD, range) } \\
\text { (ppt, lipid) }\end{array}$ & $\begin{array}{l}\text { Locksmith }(n=3) \\
\text { mean (SD, range), } \\
\text { (ppt, lipid) }\end{array}$ & & \\
\hline $\begin{array}{l}\text { TetraCDD } \\
\text { PentaCDD } \\
\text { HexaCDD } \\
\text { HeptaCDD } \\
\text { OctaCDD }\end{array}$ & $\begin{array}{c}3 \cdot 6(2 \cdot 0, \mathrm{ND}-13 \cdot 0) \\
14 \cdot 9(6 \cdot 1,4 \cdot 4-37 \cdot 0) \\
93 \cdot 5(40 \cdot 4, \mathrm{ND}-252 \cdot 0) \\
94 \cdot 9(54 \cdot 4,21-280 \cdot 0) \\
637(344,170-1524)\end{array}$ & $\begin{array}{c}4 \cdot 4(3 \cdot 9,1 \cdot 7-8 \cdot 4) \\
10 \cdot 2(9 \cdot 3,4 \cdot 5-20 \cdot 0) \\
65 \cdot 8(63 \cdot 8,38 \cdot 8-117) \\
85 \cdot 5(42 \cdot 7,29 \cdot 4-215) \\
684(465,382-1596)\end{array}$ & $\begin{array}{c}3 \cdot 3(1 \cdot 1,2 \cdot 0-5 \cdot 0) \\
11 \cdot 0(3 \cdot 1,4 \cdot 9-16 \cdot 0) \\
85 \cdot 9(30 \cdot 4,56 \cdot 5-154) \\
110 \cdot 7(37 \cdot 9,42 \cdot 0-167) \\
1051(438,509-1839)^{\star \star \star}\end{array}$ & $\begin{array}{c}3 \cdot 9(1 \cdot 0,3 \cdot 2-5 \cdot 0) \\
12 \cdot 2(3 \cdot 7,8 \cdot 6-16 \cdot 0) \\
107 \cdot 7(45 \cdot 5,63 \cdot 0-154) \\
139 \cdot 3(45 \cdot 4,87-167) \\
1387(449,941-1839) \star \star \star\end{array}$ & $\begin{array}{c}0 \cdot 06 \\
0 \cdot 24 \\
1 \cdot 77 \\
19 \cdot 1 \\
129\end{array}$ & $\begin{array}{l}0 \cdot 07 \\
0 \cdot 3 \\
2 \cdot 2 \\
12 \cdot 1 \\
43 \cdot 2\end{array}$ \\
\hline $\begin{array}{l}\text { TetraCDF } \\
\text { PentaCDF } \\
\text { HexaCDF } \\
\text { HeptaCDF } \\
\text { OctaCDF }\end{array}$ & $\begin{array}{c}2 \cdot 6(2 \cdot 0, \mathrm{ND}-10) \\
42 \cdot 7(18 \cdot 6, \mathrm{ND}-83 \cdot 3) \\
30 \cdot 2(18 \cdot 2,7 \cdot 9-76 \cdot 0) \\
22 \cdot 7(12 \cdot 4,5 \cdot 8-52 \cdot 0) \\
7 \cdot 4(6 \cdot 5, \mathrm{ND}-30 \cdot 0)\end{array}$ & $\begin{array}{c}0 \cdot 9(2 \cdot 3, \mathrm{ND}-3 \cdot 7) \\
28 \cdot 8(16 \cdot 5,11 \cdot 1-47 \cdot 1) \\
31 \cdot 1(18 \cdot 2,13 \cdot 3-60 \cdot 2) \\
20 \cdot 6(14 \cdot 8,10 \cdot 1-43 \cdot 5) \\
0 \cdot 6(1 \cdot 1, \mathrm{ND}-4 \cdot 3)\end{array}$ & $\begin{array}{l}2 \cdot 7(1 \cdot 3,1 \cdot 2-5 \cdot 3) \\
28 \cdot 1(8 \cdot 2,16 \cdot 0-43 \cdot 8) \\
52 \cdot 3(28 \cdot 7,26 \cdot 8-121)^{\star \star} \\
43 \cdot 9(30 \cdot 4,21 \cdot 0-114 \cdot 0)^{\star \star \star} \\
2 \cdot 3(4 \cdot 2, \mathrm{ND}-10)\end{array}$ & $\begin{array}{l}3 \cdot 2(2 \cdot 1,1 \cdot 2-5 \cdot 3) \\
36 \cdot 6(7 \cdot 0,29 \cdot 9-43 \cdot 8) \\
86(30 \cdot 8,63 \cdot 0-121)^{\star \star \star} \\
88 \cdot 6(24 \cdot 3,68 \cdot 9-114)^{\star \star \star} \\
6(4 \cdot 1, \mathrm{ND}-10)\end{array}$ & $\begin{array}{l}0 \cdot 11 \\
0 \cdot 77 \\
5 \cdot 02 \\
20 \cdot 2 \\
24 \cdot 8\end{array}$ & $\begin{array}{r}0 \cdot 4 \\
1 \cdot 9 \\
4 \cdot 9 \\
11 \cdot 3 \\
55 \cdot 4\end{array}$ \\
\hline \multirow{2}{*}{$\begin{array}{l}\text { Total PCDDs } \\
\text { Total PCDFs } \\
\text { Total PCDDs } \\
\text { and PCDFs }\end{array}$} & $\begin{array}{l}825(454,245-1983) \\
93 \cdot 7(36 \cdot 2,32 \cdot 6-156 \cdot 0)\end{array}$ & $\begin{array}{l}850(590,500-1079) \\
80 \cdot 1(50 \cdot 8,42 \cdot 5-152 \cdot 7)\end{array}$ & $\begin{array}{c}1262(484,702-2178)^{\star \star \star} \\
133 \cdot 0(68 \cdot 1,75 \cdot 3-292)^{\star}\end{array}$ & $\begin{array}{l}1650(515,150-2178)^{\star \star \star} \\
217 \cdot 6(64 \cdot 5,175-291 \cdot 9)^{\star \star \star}\end{array}$ & - & $\begin{array}{l}- \\
-\end{array}$ \\
\hline & $918(432,279-2131)$ & $930(636,578-2109)$ & $1395(537,794-2470)^{\star \star \star}$ & $18 \cdot 68(570,1336-2470)^{\star \star \star}$ & - & - \\
\hline Toxic equivalents & $42 \cdot 9(15 \cdot 7,17 \cdot 3-76 \cdot 4)$ & $34 \cdot 3(11 \cdot 6,20 \cdot 5-63 \cdot 5)$ & $39 \cdot 7(11 \cdot 9,24 \cdot 3-66 \cdot 1)$ & $49 \cdot 4(14 \cdot 7,38 \cdot 5-66 \cdot 1)$ & - & - \\
\hline
\end{tabular}

${ }^{\star} \mathrm{P}<0.05 ;{ }^{\star \star} \mathrm{P}<0.01 ;{ }^{\star \star \star} \mathrm{P}<0.001 ; \mathrm{ND}=$ not detectable.

inspections and repairs of the filters and inside the ovens. In the past, this work was performed by these workers without personal protective equipment; later, simple dust masks, rather than approved vapour and particle protective respirators, were used while performing these duties. Currently workers at this incinerator wear P-3 masks and single-use protective suits for this work. The second cohort was a group of 11 employees of a newer municipal waste incinerator in northern Germany that were selected so as to be group matched for age ( \pm 10 years), sex, and race with the first cohort. Thus, according to similar questionnaire data, these workers were all white men with mean (range) age of 52 (42-58) years. This group had a mean (range) of $20.7(14-24)$ years working in municipal waste incineration and included eight workers with the job classification of locksmith. The third cohort consisted of 25 workers from a group of 85 volunteers from the German general population with no known occupational exposure to PCDDs or PCDFs. ${ }^{6}$ They were also group matched to the first cohort for age ( \pm 10 years), sex, and race. Thus, these workers were all white men with a mean (range) age of 41 (33-52) years.

For each of the men in these cohorts, whole blood samples (about $100 \mathrm{ml}$ ) had been collected by routine venepuncture between 1989 and 1991 with full compliance to all laws and regulations of the Federal Republic of Germany and with the identity of all blood donors kept anonymous after collection. Blood samples were collected in chemically clean containers and kept frozen at $-20^{\circ} \mathrm{C}$ until the time of analysis. Also, samples of the slag and fly ash from the older municipal waste incinerator were obtained for analysis in 1990. For all samples, techniques for extraction, clean up, and dioxin and dibenzofuran analysis by gas chromatography-mass spectrometry (GC-MS) were performed, as previously described, ${ }^{7}$ by a laboratory that has met the certification standards of the World Health Organisation. Results were recorded for the concentrations of each of the 10 main
PCDD and PCDF congeners (tetraCDD, pentaCDD, hexaCDD, heptaCDD, octaCDD, tetraCDF, pentaCDF, hexaCDF, heptaCDF, octaCDF), total PCDDs, total PCDFs, total PCDDs and PCDFs, and toxic equivalents, according to the International Dioxin Toxic Equivalent Factors method for comparing relative toxicities of various congeners, such that the toxic equivalent is thought to approximate the total dioxin toxicity from all dioxin and dibenzofuran congeners in a mixture. As the results were roughly normally distributed, differences in mean concentrations between cohorts were compared with Student's $t$ test, and a P value $<0.05$ was considered to be significant.

\section{Results}

The table presents the means (SD, ranges) for the 2,3,7,8-(toxic) chlorine substituted PCDD and PCDF concentrations in the blood of the 25 controls from the German general population, the 11 workers from the newer incinerator and the 10 workers from the older incinerator, as well as the three most heavily exposed workers from the older incinerator (all in parts/trillion (ppt) on a lipid basis), and the concentrations of PCDD and PCDF congeners in the slag and fly ash from the older incinerator (in parts/billion (ppb)). When the mean concentrations for the 10 workers at the older incinerator were compared with the controls, significant increases were found for octaCDD $(P<0.001)$, hexaCDF $(P<0.01)$, heptaCDF $(P<$ $0.001)$, total PCDD $(P<0.001)$, total PCDF $(P<0.05)$, and total PCDD and PCDF $(P<$ $0.001)$. When the mean concentrations for the workers at the older incinerator with the greatest potential exposure (the three locksmiths) were compared with the controls, the significance of the increases in hexaCDF and total PCDF increased $(P<0.001)$ with no change in the significance of the other differences. No significant differences were found between the concentrations in the 11 workers at the newer incinerator and the controls. The 
main PCDD and PCDF congeners identified in the slag and fly ash from the older incinerator were heptaCDD, octaCDD, hexaCDF, heptaCDF, and octaCDF.

\section{Discussion}

Our results for concentrations of PCDD and PCDF congeners in workers at an older German incinerator are similar to those previously reported for workers from the United States at an older New York City incinerator where hexaCDF, total PCDFs, and total PCDDs and PCDFs were found to be significantly increased as well as concentrations of pentaCDD, hexaCDD, and tetraCDF. ${ }^{6}$ The New York City study was based on pooled blood samples and required certain assumptions for analysis - for example, the SDs for the pooled samples were assumed to be similar to those obtained from individual samples in other populations - that made interpretation of the significance of the results difficult. As our study is based on individual samples, the statistical conclusions can be assumed to be more reliable. Furthermore, in this study, it was possible to identify those workers with the greatest likelihood of exposure to slag and ash contaminated with PCDDs and PCDFs as having the most significant increases of blood concentrations of PCDDs and PCDFs. It is also of interest to note that the specific congeners found to be significantly increased in these workers correspond to those congeners found in the slag and fly ash to which they were exposed, which contained octaCDD, hexaCDF and heptaCDF, among others. This suggests that the slag or fly ash or both may have been a source of exposure in these workers, although other potential sources of exposure-for example, diet-were not accounted for in this study. Thus, this study provides some supporting evidence for the bioavailability of dioxins and dibenzofurans in slag and fly ash from a municipal waste incinerator, which has important implications for the handling and disposal of such incinerator wastes.

Conversely, the failure to find significant increases of dioxins and dibenzofurans in the blood of workers at the newer incinerator may indicate that modern pollution controls can effectively limit such exposures. This effect could not be attributed to differences in age or work exposure between the two groups of incinerator workers, as the cohort at the newer municipal incinerator was actually slightly older and had more incinerator work experience than the cohort at the older incinerator. Also, this effect could not be attributed to differences in job categories between the two cohorts. In fact, the cohort from the newer incinerator included more men in the potentially high exposure job classification of locksmith than did the cohort from the older incinerator, and this subgroup of locksmiths at the newer incinerator had blood concentrations of PCDDs and PCDFs that were indistinguishable from the controls or the cohort as a whole (data not shown). As other potential sources of exposure to dioxin and dibenzofuran in these two cohorts were not accounted for, it cannot be definitively concluded that the differences in concentrations of PCDDs and PCDFs between the two groups of incinerator workers were due to the differences in pollution control technology at the two incinerators.

Nevertheless, these results suggest that further study of the bioavailability of PCDDs and PCDFs from incinerator slag and fly ash is warranted, particularly with regard to potential health effects from such levels of exposure and possible control of such exposures with modern technology.

1 Schecter AJ. Dioxins and related chemicals in humans and the environment. In: Gallo $M$, Scheuplein RJ, Vander Heijden KA, eds. Banbury Report 35: Biological basis for risk assessment of dioxins and related compounds, Cold Spring Harbor, NY: Cold Spring Harbor Laboratory, 1991:169-213.

2 Huff JE, Haseman JK. Long-term chemical carcinogenesis experiments for identifying potential human cancer hazards: collective database of the national cancer institute and national toxicology program (1976-1991). Environ Health Perspect 1991;96:23-31.

3 Schecter AJ, ed. Dioxins and health. New York: Plenum Press, 1994.

4 Lustenhouwer JWA, Olie K, Hutzinger O. Chlorinated dibenzo-p-dioxins and related compounds in incinerator effluents: a review of measurements and mechanisms of formation. Chemosphere 1980;9:501-22.

5 Tong HY, Karasek FW. Comparison of PCDD and PCDF in flyash collected from municipal incinerators of different countries. Chemosphere 1986;15:1219-24.

6 Schecter AJ, Malkin R, Päpke O, Ball M, Brandt-Rauf PW. Dioxin levels in blood of municipal incinerator workers. Medical Science Research 1991;19:331-2.

7 Päpke O, Ball M, Lis ZA, Scheunert K. Determination of PCDD/PCDF in whole blood from persons involved in fire incidents. Chemosphere 1990;20:959-66. 